\title{
A Comparative Study between Bupivacaine (S75-R25) and Ropivacaine in Spinal Anesthesia for Labor Analgesia
}

\author{
Celso Schmalfuss Nogueira, TSA ${ }^{1}$, Luciana Cavalcanti Lima ${ }^{2}$, Valter Cesar Paris ${ }^{3}$, Priscila Milhomem Neiva ${ }^{4}$, \\ Erica Tanaka Otani ${ }^{5}$, Roberto de Oliveira Couceiro, TSA ${ }^{6}$, Fabio Burim ${ }^{7}$, Jonas Antônio Franco Ferreira Junior ${ }^{5}$, \\ Patrícia Cadecaro ${ }^{9}$
}

Summary: Nogueira CS, Lima LC, Paris VC, Neiva PM, Otani ET, Couceiro RO, Burim F, Ferreira Junior JAF, Cadecaro P - A Comparative Study between Bupivacaine (S75-R25) and Ropivacaine in Spinal Anesthesia for Labor Analgesia.

Background and objectives: Spinal anesthesia is used for relief of pain during labor and it is associated with low indices of complications. Studies with levorotatory enantiomers of local anesthetics demonstrate higher safety due to the lower cardiotoxicity. The objective of this study was to evaluate the latency and duration of analgesia and maternal and fetal repercussions with bupivacaine (S75-R25) and ropivacaine in spinal anesthesia for labor analgesia.

Methods: A prospective, double-blind, randomized clinical assay was undertaken with 49 labouring parturients with low risk, with indication of vaginal delivery, ages 15 to 35 years, ASA I or II, divided into two groups: GI - 0.25\% bupivacaine (S75-R25); GII - 0.20\% ropivacaine.

Results: A statistically significant difference was observed between the two groups 30 minutes after the spinal anesthesia, and pain scores were higher in the ropivacaine group. Statistically significant differences were not observed regarding the latency of analgesia, sensorial level of the blockade, volume of local anesthetic, rescue dose, duration of labor and analgesia, frequency of instrument-assisted labor, hemodynamic changes, Apgar scores or umbilical cord blood $\mathrm{pH}$, and incidence of adverse events.

Conclusions: The use of bupivacaine (S75-R25) and ropivacaine in labor analgesia provided good conditions for spinal anesthesia with small indices of adverse events.

Keywords: ANALGESIA, Labor; ANESTHESICS, Local: bupivacaine in excess enantiomeric, ropivacaine; ANESTHESICS TCHNICS, Regional: peridural block.

Financial support: Both main investigators received a financial grant from the Laboratório Cristália.

[Rev Bras Anestesiol 2010;60(5): 484-494] @Elsevier Editora Ltda.

\section{INTRODUCTION}

Bupivacaine is a local anesthetic with high-potency and long-duration and differential sensorial-motor blockade ${ }^{1}$. It is presented as a racemic mixture composed of $50 \%$ of the $\mathrm{S}$ isomer and $50 \%$ of the $\mathrm{R}$ isomer (S50-R50), and its use in obstetrics has been questioned by Albright throu-

Received from the Instituto Materno-Infantil Prof. Fernando Figueira, Irmandade da Santa Casa da Misericórdia de Santos.

1. Specialization in Pharmacology (lato sensu), Responsible for the CET

2. Master's degree in Maternal-Infantile Health of the Instituto de Medicina Integral Prof.

Fernando Figueira (IMIP), Professor of the Escola Pernambucana de Medicina (BVIMIP),

Anesthesiologist of the Maternal-Infantile Anesthesiology Department of IMIP.

3. Certification in the area of Pain Performance, Assistant of the Anesthesiology Department

of Santa Casa de Santos.

4. Anesthesiology Resident of the CET/SBA IMIP.

5. Anesthesiology Resident of the CET of Santa Casa de Santos.

6. Instructor of the CET/SBA IMIP.

7. Anesthesiology Resident of the CET of Santa Casa de Santos.

8. Medical Manager of Laboratório Cristália.

Submitted on October 15, 2009.

Approved on May 3, 2010.

Correspondence to:

Dr. Celso Schmalfuss Nogueira

Avenida Joaquim Montenegro, 22, apt ${ }^{\circ} 41$, Ponta da Praia

11035-000 - Santos, SP, Brazil

E-mail: nogueira@bignet.com.br gh the publication of clinical reports of cardiotoxicity in $1979^{2}$. Clinical studies on stereoselectivity demonstrated that a large proportion of bupivacaine toxicity is due to its dextrorotatory isomer R (+). Levorotatory isomers of local anesthetics showed more clinical safety due to their lower cardio- and neurotoxicity ${ }^{3,4}$. The epidural administration of levobupivacaine (100\% of the $S$ isomer) is associated with lower intensity of the motor blockade, which is apparently dose-dependent when used concentrations of $0.0625 \%$ and $0.5 \%{ }^{5}$.

A $50 \%$ enantiomeric excess bupivacaine (S75-R25) refers to the solution that contains $75 \%$ of the $S$ isomer and $25 \%$ of the $\mathrm{R}$ isomer. The objective of this mixture is to join the safety of the levorotatory isomer with the efficacy of the motor blockade of racemic bupivacaine.

Regarding the use of stereoisomers in labor analgesia, it has been demonstrated that ropivacaine has good maternalfetal results with adequate analgesia, minimal motor blockade, and elevated Apgar scores and adaptability and neurologic capacities ${ }^{6}$.

The objective of the present study was to evaluate the quality of analgesia and maternal and fetal repercussion of bupivacaine (S75-R25) and ropivacaine in spinal anesthesia for labor analgesia. 


\section{METHODS}

This study was conducted in two hospitals specialized on the care of parturientss: the Instituto de Instituto de Medicina Integral Professor Fernando Figueira (IMIP) in Recife-PE, and Santa Casa de Misericórdia de Santos in Santos-SP, after approval by the Ethics on Research Committee (CEP, from the Portuguese). One of the CEPs did not approve the inclusion of underage patients.

A prospective, double-blind, randomized clinical assay was undertaken to compare the quality of analgesia and the intensity of the motor blockade of $0.25 \%$ bupivacaine (S75-R25) and $0.20 \%$ ropivacaine in continuous spinal anesthesia for labor analgesia.

Patients were included in the study after signing the informed consent. Forty-nine parturientss of low risk in labor, with indication of vaginal delivery, physical status ASA I or II were included in the study and randomly divided into two groups: $\mathrm{GI}-0.25 \%$ bupivacaine (S75-R25) and Gll $-0.20 \%$ ropivacaine.

Parturientss were excluded from the study for the following reasons. Those with relative or absolute contraindications to vaginal delivery and continuous spinal anesthesia; history of hypersensitivity to the local anesthetics; use of opioids during labor; lack of pre-natal follow-up; labor lasting more than 12 hours or less than 1 hour; previous cesarean section; complications of pregnancy such as placenta previa, preeclampsia or eclâmpsia; maternal-fetal malnutrition; important accidents during pregnancy; spinal lesions, peripheral neuropathies or any other neurologic disorders that lead to changes of sensitivity and/or motricity; decompensated diabetes or hypertension; history of alcohol and/ or drug abuse; cardiopathies, especially myocardiopathies and valvulopathies; important cognitive changes; changes in safety exams (hemoglobin, hematocrit, fasting blood glucose, urinalysis, syphilis serology, and HIV); twin pregnancy; signs of intrauterine distress, and abnormalities of fetal vitality, prematurity, or important delayed labor, noncephalad presentations, small or large for gestational age, and fetal malformations.

The following parameters were evaluated:

1. Latency of analgesia (time from the administration of the local anesthetic and maximal level of the sensorial blockade).

2. Level of sensorial blockade as determined by the loss of thermal and pain sensitivity in sacral, lumbar, and thoracic dermatomes.

3. Time until the solicitation of the first rescue dose (of the local anesthetic solution by the parturient or the visual analogue scale $\mathrm{VAS} \geq 3$ ).

4. Pain scores as determined by the visual analogue scale.

5. Degree of motor blockade evaluated by the RAM (rectus abdominis muscle) scale and ambulation.

6. Duration of analgesia (time from the administration of the local anesthetic and the end of the second stage of labor).

7. Frequency of instrument-assisted birth and total volume of local anesthetic used.
8. Degree of vitality of the newborns using the Apgar score in the fifth minute and neonatal acidosis, defined as the $\mathrm{pH}$ of umbilical cord blood below 7.20.

A venous access was secured before the anesthetic blockade with an $18 \mathrm{G}$ catheter, and patients were monitored with cardioscope, pulse oximeter, and non-invasive blood pressure. The time of the beginning of the procedure and initial pain score were recorded. Afterwards, lumbar puncture was performed with an 18G Tuohy needle using the median approach and the epidural catheter was inserted and fixed.

Pregnant patients in $\mathrm{Gl}$ and Gll received $10 \mathrm{~mL}$ of one of the anesthetic solutions used in the study according to prior randomization.

The study solutions were prepared by the product development sector of the Laboratory Cristália' ${ }^{\mathrm{TM}}$ in $20 \mathrm{~mL}$ vials.

Vials were identified with the allocation number of patients and the volume of the vial. The random distribution of the study was done by the laboratory. Motor blockade, pain scores, and the need of rescue doses of the local anesthetic were evaluated every 30 minutes $(\mathrm{Mi}=$ before analgesia; $\mathrm{M} 30=30$ minutes after analgesia; $\mathrm{M} 60=60$ minutes after analgesia and so forth, until the end of labor). A rescue dose of $5 \mathrm{~mL}$ of the same local anesthetic in the same concentration of that used at the beginning of analgesia was administered whenever the parturient complained of pain of 3 or more than 3 in the visual analogue scale, including during the expulsive period. In case of any degree of motor blockade that could interfere with the evolution of labor, the concentration of the rescue dose of the local anesthetic was reduced by $50 \%$.

In the statistical analysis of the results, non-parametric Chisquare, Fisher exact, and Mann-Whitney test, the parametric non-paired $t$ test, and linear regression test were used with a level of significance of $0.5 \%(p<0.05)$. When $0.05<p<0.10$, it was considered a tendency towards significance ${ }^{7}$.

\section{RESULTS}

At the end of the study, 49 patients were included, of which 23 (Gl) received $0.25 \%$ bupivacaine (S75-R25) and 26 (GII) $0.20 \%$ ropivacaine.

Both groups were homogenous regarding age $(p=0.70)$, weight $(p=0.58)$, height $(p=0.41)$, BMI $(p=0.95)$, and use of concomitant medications $(p=0.69)$. In the bupivacaine group the mean age was 24.2 years, mean weight of $69 \mathrm{~kg}$, and mean BMI of $27.01 \mathrm{~kg} \cdot \mathrm{m}^{-2}$, while in the ropivacaine group the mean age was 23.7 years, mean weight of $70.3 \mathrm{~kg}$, and mean BMI of $27.05 \mathrm{~kg} \cdot \mathrm{m}^{-2}$ (Table I).

As for the evolution of labor, the mean time for analgesia was 6.7 minutes in $\mathrm{Gl}$, and 11.4 minutes in GII $(p=0.07)$. The mean latency for sensorial blockade of the T10 dermatome was 23.5 and 28.9 minutes $(p=0.40)$ and for $T 12$ was 14.4 and 21.2 minutes for GI and GII, respectively, 
Table I - Biodemographic Data

\begin{tabular}{|c|c|c|c|}
\hline & G I $(n=23)$ & $G$ II $(n=26)$ & Test \\
\hline Age (years) & $24.2 \pm 6.1(24.0)^{*}$ & $23.7 \pm 4.6(23.5)^{*}$ & $t=0.37$ \\
\hline Minimum - Maximum & $17-35$ & $15-34$ & $p=0.7098$ \\
\hline Minimum - Maximum & $51-82,7$ & $59-93$ & $p=0.5811$ \\
\hline Hight (m) & $1.60 \pm 0.05(1.60)^{*}$ & $1.61 \pm 0.06(1.60)^{*}$ & $t=0.82$ \\
\hline Minimum - Maximum & $1.47-1.70$ & $1.49-1.77$ & $p=0.4156$ \\
\hline Minimum - Maximum & $19.92-30.91$ & $23.88-32.05$ & $p=0.9555$ \\
\hline
\end{tabular}

*Média \pm Dp (mediana);

GI - bupivacaine S75-R25 at $0.25 \%$ e Gll - ropivacaine at $0.20 \%$.

without statistically significant difference between both groups (Table II).

Motor blockade and pain scores were evaluated before analgesia and every 30 minutes during labor. It was observed that the motor blockade did not differ significantly between both groups, and analgesia did not interfere with patient ambulation, with a mean time of 81.1 and 76.9 minutes for GI and GII, respectively ( $p=0.56)$. During periodic assessment of analgesia, it was observed a statistically significant difference between both groups 30 minutes after the spinal anesthesia and pain scores were higher in the ropivacaine group $(p=0.01)$.

Regarding the administration of rescue dose, a significant difference between both groups was not observed. The majority of patients required a rescue dose, $60.9 \%$ in GI, and $80.8 \%$ in GII ( $p=0.22$ ), but after 1 hour, only 6 patients $(26.1 \%)$ in the bupivacaine group required one rescue dose, while $14(53.8 \%)$ of the patients in the ropivacaine group required one or two rescue doses $(p=0.07)$. The total volume of local anesthetic used in rescue doses was similar in both groups $(p=0.19)$, with a mean of $9.9 \mathrm{~mL}$ in $\mathrm{Gl}$, and $11.8 \mathrm{~mL}$ in GII (Table III).
As for the frequency of spontaneous labor, forceps-assisted labor, or cesarean section, a difference was not observed between both groups. The frequency of cesarean sections was $4.3 \%$ in $\mathrm{GI}$, and $11.5 \%$ in GII ( $p=0.72$ ), and that of forceps-assisted labor was $17.40 \%$ in $\mathrm{GI}$, and $11.50 \%$ in GII ( $p=0.85)$ (Table IV).

A difference in Apgar score was not observed with a median of 9 in both groups $(p=0.33)$. The frequency of neonatal acidosis $(\mathrm{pH}<7.20)$ was $30.4 \%$ in $\mathrm{Gl}$, and $8.0 \%$ in $\mathrm{Gll}$ ( $\mathrm{p}=$ 0.08) (Table V).

Regarding the duration of analgesia, similar residual efficacy was observed in both groups of $73.9 \%$ and $61.5 \%$ of the patients in the bupivacaine (S75-R25) and ropivacaine groups $(p=0.53)$.

As for safety analysis, preoperative laboratorial exams such as hemoglobin, hematocrit, and fasting glucose levels were similar. Variations in blood pressure and heart rate were similar in both groups at all moments. The incidence of adverse events was very low. One patient in the bupivacaine (S75R25) group reported headache, while one patient in the ropivacaine group developed vomiting, one reported dizziness, and another complained of tingling in the lower limbs.

Table II - Labor Analgesia

\begin{tabular}{|c|c|c|c|}
\hline & $G \mid(n=23)$ & $G \|(n=26)$ & * \\
\hline \multicolumn{4}{|c|}{ Latency for the Disappearance of Pain (min) } \\
\hline $\mathrm{N}$ & 23 & 26 & $U=209.0$ \\
\hline Minimum - Maximum & $2-20$ & $2-52$ & \\
\hline \multicolumn{4}{|c|}{ Latency for Sensorial Blockade in the T10 Dermatome (min) } \\
\hline Minimum - Maximum & $2-90$ & $0-105$ & \\
\hline \multicolumn{4}{|c|}{ Latency for Sensorial Blockade in the T12 Dermatome (min) } \\
\hline $\mathrm{N}$ & 22 & 25 & $U=209.0$ \\
\hline Mean \pm SD (median) & $14.5 \pm 12.8(10.0)$ & $21.2 \pm 18.4(10.0)$ & $P=0.1594$ \\
\hline
\end{tabular}

GI - bupivacaine S75-R25 at 0.25\%; GII - ropivacaine at 0.20\%; SD - standard deviation; * Mann-Whitney Test. 
Table III - Rescue Dose

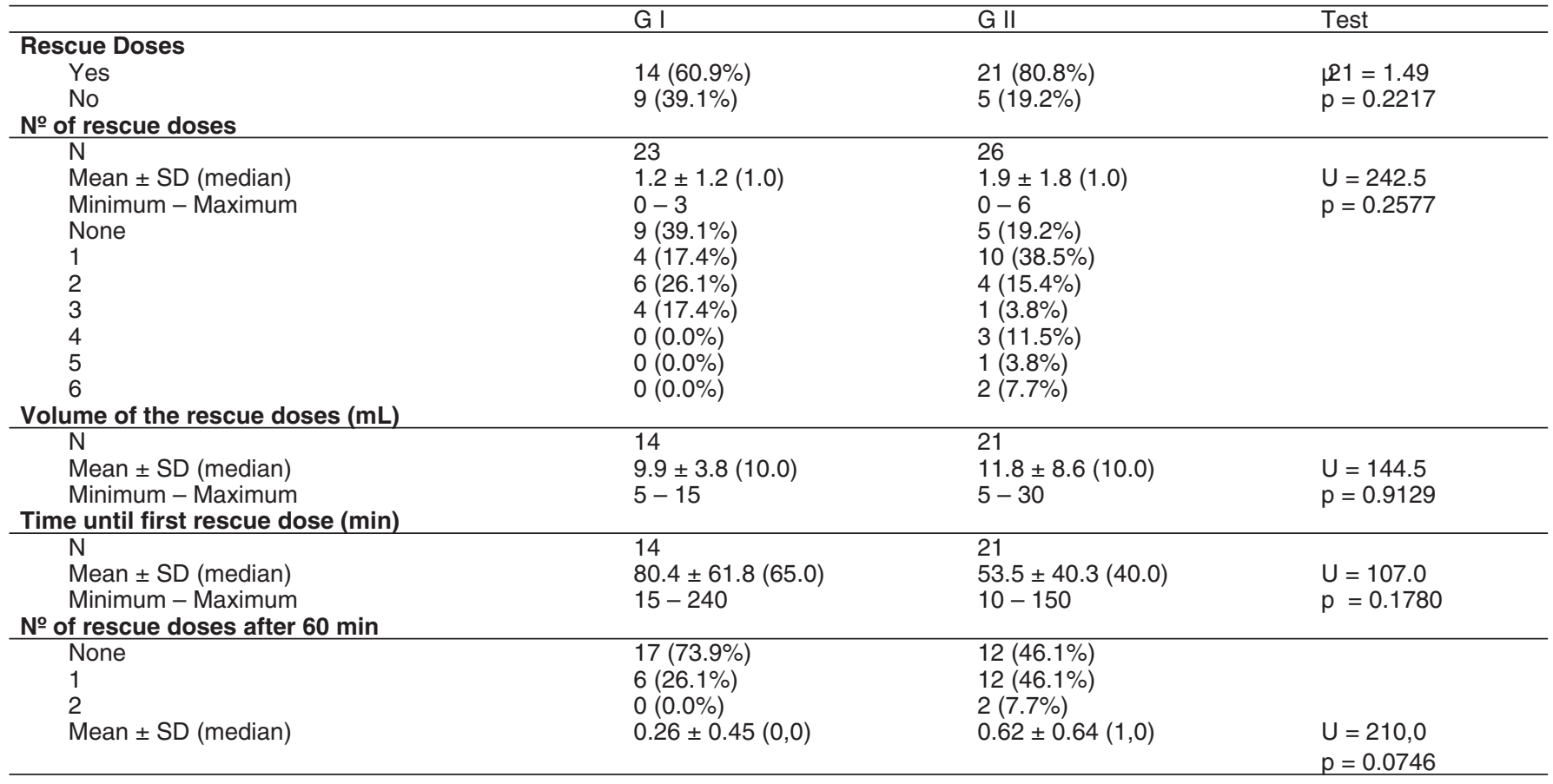

GI - bupivacaine S75-R25 at 0.25\%; Gll - ropivacaine at $0.20 \%$; SD - standard deviation.

Table IV - Labor Evolution

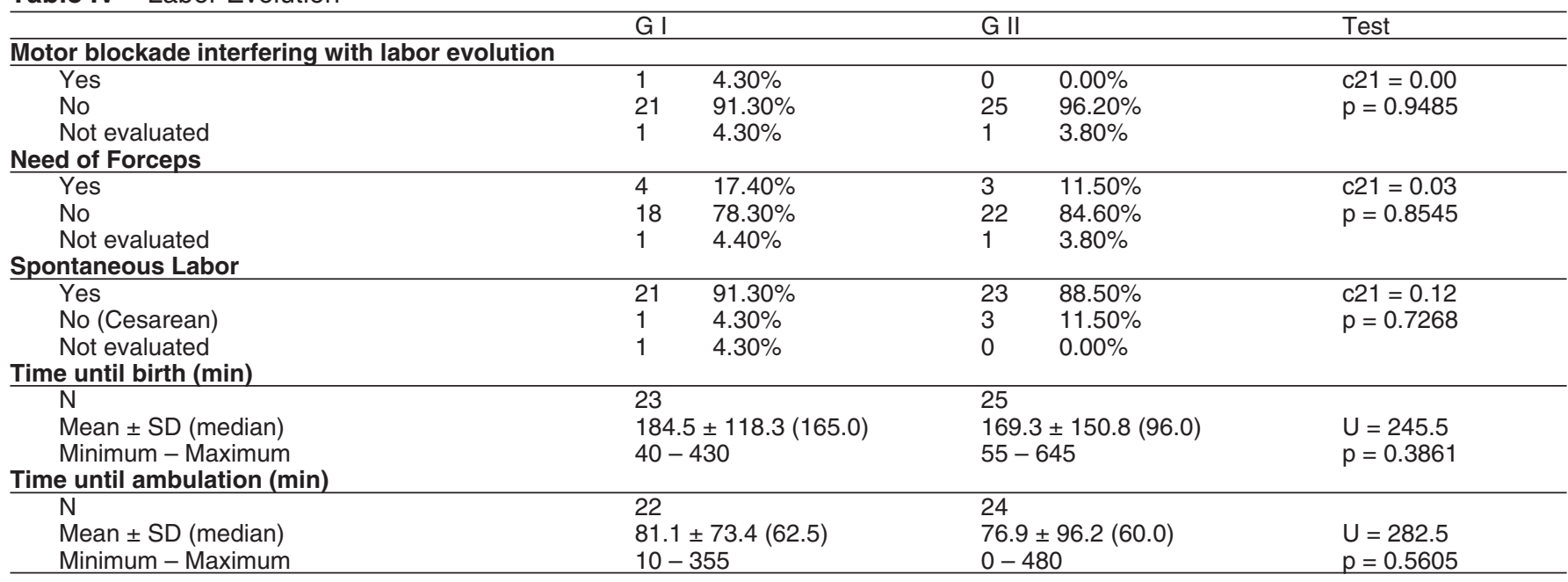

GI - bupivacaine S75-R25 at $0.25 \%$; Gll - ropivacaine at $0.20 \%$.

Tabela V - Evaluation of the Fetus

\begin{tabular}{|c|c|c|c|}
\hline pH of the umbilical cord & GI & G II & $\begin{array}{l}\text { Test } \\
(<7.2 \text { vs } \geq 7.2)\end{array}$ \\
\hline$<7.2$ & $30.4 \%$ & $7.7 \%$ & $\mathrm{X} 2_{1}=3.02$ \\
\hline$\geq 7.2$ & $56.5 \%$ & $80.8 \%$ & $p=0.0820$ \\
\hline No results & $4.3 \%$ & $0.0 \%$ & \\
\hline Mean \pm SD (median) & \multirow[t]{2}{*}{$7.223 \pm 0.15(7.247)$} & \multirow[t]{2}{*}{$7.266 \pm 0.08(7.276)$} & $p=0.3055$ \\
\hline Apgar (5 min) & & & \\
\hline Median & 9.0 & 9.0 & \\
\hline Minimum & 7 & 7 & \\
\hline Maximum & 10 & 10 & \\
\hline
\end{tabular}

GI - bupivacaine S75-R25 at 0.25\%; GIl - ropivacaine at $0.20 \%$. 


\section{DISCUSSION}

Clinical studies with levorotatory enantiomers of local anesthetics demonstrated greater clinical safety due to less neuroand cardiotoxicity ${ }^{3,4}$. The literature has demonstrated that the administration of epidural bupivacaine (S75-R25) is associated with lower intensity of motor blockade 8,9 , besides preserving the differential blockade of racemic bupivacaine, representing an advantage of its use in labor analgesia 10,11,12,13. Parturientss who participated in this study received $0.25 \%$ bupivacaine (S75-R25) and $0.20 \%$ ropivacaine.

Studies based on up-and-down sequential allocation method have demonstrated the lack of statistically significant differences in the minimal anesthetic concentration between levobupivacaine and ropivacaine ${ }^{14,15}$, besides suggesting that the latter is possibly less potent than racemic bupivacaine. However, other clinical studies comparing epidural racemic bupivacaine and ropivacaine in labor analgesia revealed contradictory results. On the other hand, recent studies have demonstrated that ropivacaine and bupivacaine are equipotent. Those considerations are even more inconclusive when comparing ropivacaine with bupivacaine (S75-R25) due to the lack of data in the literature. Therefore, the authors decided to use the concentrations commercially available in the Brazilian market.

Those patients who received $0.25 \%$ bupivacaine (S75R25) presented at 30 minutes of analgesia lower pain scores than those who received ropivacaine. The incidence of spontaneous ambulation and motor blockade by the RAM scale did not differ between both groups.

Nakamura et al. ${ }^{6}$, investigating labor analgesia in a clinical randomized study, evaluated 33 patients who received epidural bupivacaine, ropivacaine, or levobupivacaine all at a concentration of $0.125 \%$, and concluded that the motor blockade was more intense with levobupivacaine than with bupivacaine or ropivacaine.

Those results are conflicting with ours since when analyzing the motor blockade we observed that it was similar in both bupivacaine (S75-R25) and ropivacaine groups because there is a predominance of levorotatory isomers in both solutions ${ }^{13}$. Despite in vitro studies having suggested that both isomers of bupivacaine are equipotent for the motor blockade ${ }^{20}$, a more recent in vitro study indicated that that the dextrorotatory is more potent than the levorotatory in inhibiting sodium channels ${ }^{21}$, justifying the presence of lower motor blockade when a mixture with greater concentration o the $S$ isomer is used.

Indeed, a clinical study comparing $0.5 \%$ racemic bupivacaine with $0.5 \%$ bupivacaine (S75-R25) in 44 patients undergoing spinal anesthesia for vascular or orthopedic procedures of the lower limbs demonstrated that the degree of motor blockade was more intense in the racemic bupivacaine group ${ }^{8}$.

The blockade of skeletal muscles is one of the most undesirable effects during labor analgesia attributed to local anes- thetics due to the risk of increasing instrument-assisted labor, longer duration of labor, and maternal dissatisfaction 22,23. Labor analgesia when properly conducted does not interfere with uterine dynamics, and it does not prolong the duration of the first stage of labor. For the second stage, care regarding the volume and concentration of the local anesthetic should be taken to preserve muscular strength ${ }^{24,25}$. The use of lower concentrations of local anesthetic in spinal anesthesia does not seem to affect the evolution of labor ${ }^{26}$. In our study, a difference in the incidence of cesarean sections or use of forceps was not observed between the study groups, which was similar to that reported in the literature ${ }^{6,24,27}$, even using concentrations of $0.25 \%$ bupivacaine, considered a little more elevated than those used more often, i.e., below $0.25 \%$.

The present study demonstrated a tendency towards a lower latency in the bupivacaine (S75-R25) group, which might be advantageous in situations in which fast pain relief is desirable such as labor ${ }^{13}$.

Lower pain scores at 30 minutes observed in the bupivacaine (S75-R25) group are similar to those reported in another study that compared the analgesia of racemic bupivacaine to that of bupivacaine (S75-R25). Those authors observed that pain intensity during the evolution of labor was similar between groups, except at 45 minutes, when patients on $0.25 \%$ bupivacaine (S75-R25) presented lower pain scores ${ }^{11}$.

It is important to consider that those two last results could be explained by the fact that the group who used $0.25 \%$ bupivacaine (S75-R25) received higher concentration of anesthetics than the group who received ropivacaine $(0.2 \%)$. Note that the pharmacological profile of anesthetics with greater proportion of the levorotatory isomer allows increasing its concentration with little change in the intensity of the motor blockade ${ }^{13}$.

In the present study, newborns in both groups presented good vitality. Those born from mothers who receive bupivacaine (S75-R25) had a statistical tendency for greater incidence of acidosis $(\mathrm{pH}<7.2)$. However, those results were not clinically significant since Apgar scores were elevated and similar in both groups.

In our study, it was not possible to correlate the incidence of acidosis with the time the newborn remained in the birth canal.

Investigating the efficiency of levobupivacaine (100\% levorotatory bupivacaine) and bupivacaine (S75-R25) in spinal anesthesia, some authors observed a low incidence of side effects, good receptivity of the method by patients, absence of transitory postoperative neurologic symptoms, and adequacy of motor and sensorial blockades, which indicated the safety of those solutions in lumbar spinal anesthesia ${ }^{9}$. In the present study, we observed a low frequency of adverse effects, and they were all considered not severe.

When comparing two local anesthetics, bupivacaine (S75R25) and ropivacaine, whose profile is associated with lower neuro- and cardiotoxicity, we conclude that both drugs in low concentrations can be used for labor analgesia. 


\section{REFERÊNCIAS / REFERENCES}

01. Glaser C, Marhofer P, Zimpfer G - Levobupivacaine versus racemic bupivacaine for spinal anesthesia. Anesth Analg, 2002;94:194-198.

02. Albright GA - Cardiac arrest following regional anesthesia with etidocaine or bupivacaine. Anesthesiology, 1979;51:285-286.

03. Simonetti MPB, Valinetti EA, Ferreira FMC - Avaliação da atividade anestésica local da S(-) Bupivacaína: estudo experimental in vivo em nervo ciático de rato. Rev Bras Anestesiol, 1997;47:425-434.

04. Imbelloni LE, Beato $L$ - Comparação entre bupivacaína racêmica (S50-R50) e mistura enantiomérica de bupivacaína (S75-R25), ambas Isobáricas, a $0,5 \%$ em raquianestesia. Estudo em cirurgias ortopédicas. Rev Bras Anestesiol, 2001;51:369-376.

05. Foster RH, Markham A. Levobupivacaine: a review of its pharmacology and use as a local anesthetic. Drugs, 2000;59:551-557.

06. Nakamura G, Castiglia YMM, Nascimento Junior P et al - Bupivacaína, ropivacaína e levobupivacaína em analgesia e anestesia de parto. Repercussões materno-fetais. Rev Bras Anestesiol, 2000;50: 105-111.

07. Curi PR - Metodologia e análise da pesquisa em ciências biológicas. 2a Edição, Botucatu: Editora Tipomic, 1998;215.

08. Goncalves RF, Lauretti GR, Mattos AL - Estudo Comparativo entre bupivacaína a 0,5\% e mistura enantiomérica de bupivacaína (S75R25) a 0,5\% em anestesia peridural. Rev Bras Anestesiol, 2003;53: 169-176.

09. Delfino J, Vale NB - Bupivacaína levógira a 0,5\% pura versus mistura enantiomérica de bupivacaína (S75-R25) a 0,5\% em anestesia peridural para cirurgia de varizes. Rev Bras Anestesiol, 2001;51:474-482.

10. Cortes CAF, Oliveira AS, Castro LFL et al - Estudo comparativo entre bupivacaina a 0,5\%, mistura enantiomérica de bupivacaína (S75-R25) a $0,5 \%$ e ropivacaína a $0,75 \%$ associadas ao fentanil em anestesia peridural para cesarianas. Rev Bras Anestesiol, 2003;53:177-187.

11. Cortes CAF, Castro LFL, Serafim MM et al - Estudo comparativo entre bupivacaína racêmica a $0,25 \%$ e bupivacaína com excesso enantiomérico de $50 \%$ (S75-R25) a 0,25\% associadas ao fentanil para analgesia de parto com deambulação da parturiente. Rev Bras Anestesiol, 2006;56:16-27.

12. Cortes CAF, Sanchez CA, Oliveira AS et al - Analgesia de parto: estudo comparativo entre anestesia combinada raquiperidural versus anestesia peridural continua. Rev Bras Anestesiol, 2007;57:39-51.

13. Duarte NMC, Caetano AMM, Lima LC et al - Estudo comparativo entre bupivacaína racêmica (S50-R50) a 0,125\% e bupivacaína em excesso enantiomérico de $50 \%$ (S75-R25) a 0,125\% e 0,25\% em anestesia peridural para analgesia de parto. Rev Bras Anestesiol, 2008;58:5-14

14. Polley LS, Columb MO, Naughton NN et al - Relative analgesic potencies of levobupivacaine and Ropivacaína for epidural analgesia in labour. Anesthesiology, 2003;99:1354-1358.

15. Benhamou D, Ghosh C, Mercier FJ - A randomized sequencial allocation study to determine the minimum effective analgesic concentration of levobupivacaine and ropivacaine in patients receiving epidural analgesia for labor. Anesthesiology 2003;99:1383-1386.

16. Polley LS, Columb MO, Naughton NN et al - Relative analgesic potencies of ropivacaine and bupivacaine for epidural analgesia in labor: implications for therapeutics indexes. Anesthesiology, 1999;90: 944-950.

17. Capogna G, Eleno D, Fusco $P$ et al - Relative potencies of bupivacaine and ropivacaine for analgesia in labor. Br J Anaesth, 1999;82:371-373.

18. Owen MD, Thomas JA, Smith T et al - Ropivacaine $0.075 \%$ and bupivacaine $0.075 \%$ with fentanyl $2 \mu \mathrm{g} / \mathrm{mL}$ are equivalent for labor epidural analgesia. Anesth Analg 2002;94:179-183.
19. Owen MD, D'Angelo R, Gerancher JC et al $-0.125 \%$ ropivacaine is similar to $0.125 \%$ bupivacaine for labor analgesia using patient controlled epidural infusion. Anesth Analg, 1998;86:527-531.

20. Aberg G - Toxicological and local anesthetic effects of optically active isomers of two local anesthetic compounds. Acta Pharmacol Toxicol, 1972;31:273-286

21. Lee-Soon S, Wang GK, Concus $A$ et al - Stereoselective inhibition of neuronal sodium channels by local anesthetics. Anesthesiology, 1992;77:324-325.

22. Robinson JO, Rosen M, Evans JM et al - Maternal opinion about analgesia for labor. A controlled trial between epidural block and intramuscular pethidine combined with inhalation. Anaesthesia, 1980;35: 1173-1181.

23. Thorp JA, Hu DH, Albin RM et al - The effect of intrapartum epidural analgesia on nulliparous labor: a randomized, controlled, prospective trial. Am J Obstet Gynecol, 1993;169:851-858.

24. Chestnut DH. Does epidural analgesia during labor affect the incidence of cesarean delivery? Reg Anesth, 1997;22: 495-499.

25. Eugenio AGB, Cavalcanti FS - Analgesia de parto condutiva - anestésicos e outros fármacos. Rev Bras Anestesiol, 1993;43:57-63.

26. Hawkins JL, Arens JF, Bucklin BA et al - Practice guideline for obstetric anesthesia: a report by American Society of Anesthesiologists. Task Force on Obstetrical Anesthesia. Anesthesiology, 1999;90:600-611.

27. Zhang J, Yancey MK, Klebanoff MA et al - Does epidural analgesia prolong labor and increase risk of cesarean delivery? A nature experiment. Am J Obstet Gynecol 2001;185:128-134.

Resumen: Nogueira CS, Lima LC, Paris VC, Neiva PM, Otani ET, Couceiro RO, Burim F, Ferreira Junior JAF, Cadecaro P - Estudio Comparativo entre la Bupivacaína (S75-R25) y la Ropivacaína en Bloqueo Epidural para Analgesia de Parto.

Justificativa y objetivos: La anestesia epidural se usa para el alivio del dolor en el parto y está asociada a bajos índices de complicaciones. Estudios con enantiómeros levógiros de los anestésicos locales, han demostrado una seguridad más elevada en función de una menor cardiotoxicidad. Este estudio quiso evaluar la latencia y la duración de la analgesia y las repercusiones maternas y fetales con el uso de la bupivacaína (S75-R25) y de la ropivacaína cuando se usan para la analgesia de parto por bloqueo epidural.

Métodos: Realizamos un ensayo clínico prospectivo, encubierto y randomizado, con 49 pacientes gestantes a término, que presentaban bajo riesgo, con indicación de parto vaginal, y una edad entre los 15 y los 35 años, ASA I o II distribuidas en dos grupos: GI - bupivacaína (S75-R25) 0,25\%; Gll - ropivacaína a 0,20\%.

Resultados: Quedó evidenciada la diferencia estadísticamente significativa entre los dos grupos, 30 minutos después de la administración de la epidural, siendo que las puntuaciones de dolor fueron más elevadas en el grupo que utilizó la ropivacaína. No se encontraron diferencias estadísticas significativas en cuanto a la latencia de la analgesia, nivel sensorial del bloqueo, volumen del anestésico local, dosis de rescate, duración del parto y de la analgesia, frecuencia de parto instrumental, alteraciones hemodinámicas, puntuaciones de Apgar o $\mathrm{pH}$ del cordón umbilical e incidencia de eventos adversos.

Conclusiones: El uso de la bupivacaína (S75-R25) y la ropivacaína para la analgesia de parto, proporcionó buenas condiciones para la realización de la anestesia epidural con pequeñas incidencias de eventos adversos.

Descriptores: ANALGESIA; ANESTÉSICO, Local: levobupivacaína en exceso enantiomérico, ropivacaína, epidural continua.

Ayuda financiera: Los dos principales investigadores recibieron una ayuda del Laboratorio Cristália. 